\title{
Heat resistance, membrane fluidity and sublethal damage in Staphylococcus aureus cells grown at different temperatures
}

\author{
G. Cebrián*, S. Condón, P. Mañas \\ Tecnología de los Alimentos, Facultad de Veterinaria de Zaragoza, Universidad de Zaragoza, C/ Miguel Servet, 177, 50013 Zaragoza, Spain
}

\section{ART ICLE INFO}

\section{Keywords:}

Food-borne pathogen

Thermal inactivation

Membrane fluidity

Sublethal injury

Growth temperature

Growth phase

Benzyl alcohol

\begin{abstract}
A B S T R A C T
In this work the influence of growth temperature $\left(10-42^{\circ} \mathrm{C}\right)$ on Staphylococcus aureus heat resistance was studied, and its relationship with the ability of cells to repair sublethal damages and with membrane fluidity was evaluated. Non-linear, convex from above survival curves were obtained, and therefore a special case of the Baranyi model was used to fit them. For exponential phase cells, heat resistance did not change with growth temperature in the range between 10 and $37^{\circ} \mathrm{C}$, but cells grown at $42^{\circ} \mathrm{C}$ were significantly more resistant, showing $D_{58}$ and shoulder length $\left(s l_{58}\right)$ values 2.5 and 4 times greater than the others, respectively. For stationary growth phase cells, an increase in growth temperature above $20^{\circ} \mathrm{C}$ resulted in an increase in $D_{58}$ values, and cells grown at $42^{\circ} \mathrm{C}$ also displayed the highest $D_{58}$ and $s l_{58}$ values. The increased heat resistance at $58^{\circ} \mathrm{C}$ of stationary growth phase cells grown at higher temperatures was coincident with the appearance of a higher proportion of sublethally damaged cells capable of recovery and outgrowth in non-selective medium. Membrane fluidity was measured at treatment temperatures, and it was observed that those cells with more rigid membranes displayed greater heat resistance (Pearson coefficient $=0.969^{* * *}$ ). Additionally, $S$. aureus cells whose membrane was fluidized through exposure to benzyl alcohol were notably sensitized against the action of heat, in a concentration-dependent manner. Results obtained in this research indicate that membrane physical state could be an important factor determining the survival capacity of bacterial cells to a heat treatment.
\end{abstract}

\section{Introduction}

Despite the widespread use and proven efficacy of thermal treatments for the inactivation of pathogen and spoilage microorganisms from foods, there is still a lack of knowledge regarding the factors influencing bacterial inactivation by heat, their mode of action, the rationale behind the kinetics of inactivation, and the responses that bacteria may develop to increase their tolerance to heat, among other aspects. This is still more relevant now, since consumer requirements for fresher and less processed foods are currently leading to a decrease in the intensity of treatments, thus requiring improved knowledge of all these factors in order to design processes that ensure food safety (Abee and Wouters, 1999; Raso and Barbosa-Cánovas, 2003).

Growth temperature is generally acknowledged as one of the main factors influencing bacterial resistance to heat (Cebrián et al., 2017; Jay, 1992; Russell, 1984). It is assumed that bacteria display greater heat resistance when grown at higher temperatures (Cebrián et al., 2008; Elliker and Frazier, 1938; Knabel et al., 1990; Mañas et al.,

\footnotetext{
Corresponding author.

Email address: guiceb@unizar.es (G. Cebrián)
}

2003; Pagán et al., 1999). Nevertheless, it should be noted that the degree of influence of growth temperature varies widely among species (Pagán et al., 1999). Although several theories have been proposed to explain this behavior, studies specifically designed to elucidate the mechanisms leading to the increased resistance of cells grown at higher temperatures are scarce.

One controversial question is whether cells grown at higher temperatures are more heat-resistant because they have more stable membranes. The cytoplasmic membrane is considered to be one of the targets of heat treatment (Hurst et al., 1973; Mackey, 2000). However, it has hitherto not been possible to establish a direct relationship between membrane damage and bacterial inactivation by heat. It has been suggested that the membrane could play an indirect role in inactivation, since its damage might result in a loss of homeostasis and a loss of cellular components that would lead to cell death (Coote et al., 1994; Kramer and Thielmann, 2016; Mackey et al., 1991; Marcén et al., 2017; Teixeira et al., 1997). Therefore, it is reasonable to suppose that changes in membranes - for instance in their structure, composition, or mechanical behavior - may influence cell survival to a variety 
of stressing agents, including heat. Beuchat and Worthington (1976) proposed that the increased heat tolerance of cells grown at higher temperatures might be related to a higher degree of saturation of the fatty acids of their membranes. Such increased saturation would lead to less fluid and thus more thermo-stable membranes reduce their fluidity, thus making membranes more thermo-stable. However, it should be noted that fatty acid composition is not the only factor that determines membrane fluidity; other components should be considered in order to determine how membrane fluidity varies with growth temperature (Denich et al., 2003; Stintzi, 2003). Furthermore, to validate this hypothesis, it would be necessary to carry out measurements of membrane fluidity at lethal temperatures, since the complex composition of bacterial membranes makes it difficult to predict a membrane's degree of fluidity at a given temperature.

On the other hand, it has also been observed that variations in growth temperature induce proteomic changes. When bacterial cells are grown close to their maximum growth temperature, a number of so-called Heat-Shock Proteins (HSPs), including chaperones and proteases, are induced (Lim and Gross, 2010; Schumann, 2007). Various authors have hypothesized that these proteins might be responsible for the increased resistance of bacterial cells grown at higher temperatures, which could be attributed to their greater ability to repair damages caused by heat exposure at different cellular levels (Herendeen et al., 1979; Schumann, 2007; Smith et al., 1991). Moreover, it is known that several heat shock proteins also exert direct stabilizing effects on cellular structures including membranes (Coucheney et al., 2005; Török et al., 1997; Tsvetkova et al., 2002).

Staphylococcus aureus is a well-known foodborne pathogen (Baird-Parker, 2000). However, in spite of its frequent isolation as a causative agent of food poisoning in almost every part of the world, little is known about the influence of physiological factors on the susceptibility of this microorganism to heat treatments. In this study we attempt to describe and characterize the influence of growth temperature on heat resistance, along with the occurrence of repairable cellular injuries, in $S$. aureus cells in both exponential and stationary growth phases. Our ultimate aim was to examine the role that membrane fluidity plays in cell survival, and to gain fundamental knowledge about the physiology of bacterial inactivation by heat treatments.

\section{Materials and methods}

\subsection{Bacterial culture and media}

Staphylococcus aureus CECT 4459 was used in this investigation. The bacterial culture was maintained frozen at $-80^{\circ} \mathrm{C}$ in cryovials. Stationary-phase cultures were prepared by inoculating $10 \mathrm{~mL}$ of tryptone soya broth (Biolife, Milan, Italy) supplemented with $0.6 \%$ yeast extract (Biolife) (TSB-YE) with a loopful of growth from tryptone soy agar supplemented with $0.6 \%$ yeast extract (TSA-YE) (Biolife) and incubating the resulting culture for $12 \mathrm{~h}$ at $37^{\circ} \mathrm{C}$ in a shaking incubator. $50 \mu \mathrm{L}$ of this culture were inoculated into $50 \mathrm{~mL}$ of fresh TSB-YE at 42, 37, 30, 20 and $10^{\circ} \mathrm{C}$. For each culture temperature, samples were taken after different incubation times to construct growth curves and to determine the time needed to reach stationary growth phase. In order to obtain stationary phase cultures (containing approximately $6-8 \times 10^{8}$ cells $/ \mathrm{ml}$; data not shown), flasks were incubated for 18, 24, 24, 48 and $344 \mathrm{~h}$ (14 days) at $42,37,30,20$ and $10^{\circ} \mathrm{C}$, respectively. Exponential-phase cells were prepared by inoculating $50 \mu \mathrm{L}$ of the stationary-phase culture into $50 \mathrm{ml}$ of fresh TSB-YE and incubating at the different temperatures listed above until optical density at $600 \mathrm{~nm}$ reached 0.8 , which corresponded to approximately $8 \times 10^{7} \mathrm{CFU} / \mathrm{mL}$.

Cell suspensions were examined under a phase contrast microscope in order to evaluate the presence of cell aggregates (Nikon Eclipse E-
400, Japan). It was determined that cell suspensions contained aggregates with a different number of cells which corresponded, on average, to 4.3 cells for exponential phase cell suspensions grown at $10-37^{\circ} \mathrm{C}$, to 2.0 cells for exponential phase cells grown at $42^{\circ} \mathrm{C}$ and for stationary phase cells grown at $10-37^{\circ} \mathrm{C}$, and to 3.1 cells for stationary phase cells grown at $42^{\circ} \mathrm{C}$.

\subsection{Heat treatments}

Heat treatments were carried out in a specially designed resistometer (Condón et al., 1993). Briefly, this instrument consists in a 350-mL vessel provided with an electrical heater for thermostation, an agitation device to ensure inoculum distribution and temperature homogeneity, and ports for the injection of microbial suspension and for the extraction of samples. Once treatment temperature had attained stability $\left( \pm 0.1^{\circ} \mathrm{C}\right), 0.2 \mathrm{~mL}$ of an appropriately diluted cell suspension was injected into the main chamber containing the treatment media. After inoculation, samples were collected at different treatment times and immediately pour-plated (Condón et al., 1996). The treatment medium was McIlvaine citrate-phosphate buffer of pH7.0 (Dawson et al., 1974).

In some experiments, benzyl alcohol (BA) (Sigma, St. Louis, USA) was added as a membrane fluidizer to the cell suspensions and to the treatment medium at concentrations ranging from $5 \mathrm{mM}$ to $20 \mathrm{mM}$ (Cebrián et al., 2016; Shigapova et al., 2005).

\subsection{Incubation of heated samples and survival counting}

The recovery medium was TSA-YE. After treatments, plates were incubated for $24 \mathrm{~h}$ at $37^{\circ} \mathrm{C}$ and, after incubation, colony-forming units (CFU) were counted. It was checked that longer incubation times did not influence survival counts (data not shown).

To estimate the percentage of sublethally injured cells, a selective recovery medium consisting in the addition of $\mathrm{NaCl}$ to TSA-YE was used. The loss of tolerance to the presence of $\mathrm{NaCl}$ is attributed to damage to the functionality and/or integrity of the cytoplasmic membrane (Mackey, 2000). The sodium chloride concentration employed was chosen in previous experiments as the maximum non-inhibitory concentration (MNIC) for untreated cells, and corresponded to 13\% w/v (Cebrián et al., 2014). It was ascertained that the MNIC was the same for all the cells regardless of growth temperature and phase. When cells were recovered in selective medium containing $\mathrm{NaCl}$, incubation times of $48 \mathrm{~h}$ were required for macroscopic colony growth. It was also checked that longer incubation times did not influence survival counts in NaCl-added medium (data not shown).

\subsection{Resistance parameters}

Survival curves were obtained by plotting the logarithm of the fraction of survivors versus treatment time. Survival curves were fitted to a special case of the Baranyi and Roberts model (Baranyi and Roberts, 1994), which considers a survival curve as a mirror image of a growth curve (Baranyi et al., 1996). Since survival curves did not show tails, this model was defined by only two parameters: the maximum inactivation rate $\left(\mu, \min ^{-1}\right)$, and the shoulder length $(s l, \min )$, that corresponds with the duration of the shoulder phase in the survival curve. For practical reasons, the maximum inactivation rate parameter $(\mu)$ was transformed into $D$ value ( $D=1 / \mu$, decimal reduction time value, minutes).

Microsoft Office Excel 2002 (Microsoft Co., Redmond, Washington, U.S.A.) with the special DMFit package (http://www.ifr.ac.uk/safety/ DMFit, IFR, Norwich, U.K.) was used to fit the data. Standard deviations, statistical significance of differences $(p<0.05)$ and Pearson's correlation coefficient were calculated using the GraphPad PRISM ${ }^{\circledR}$ sta- 
tistical software package (Graphpad Software, Inc., San Diego, CA, USA).

All resistance determinations were performed at least three times on separate working days. Error bars in figures correspond to the mean standard deviation.

\subsection{Measurement of fluorescence anisotropy}

Fluorescence anisotropy of the probe DPH (1,6-diphenyl 1,3,5-hexatriene) (Sigma, St. Louis, USA) was used to monitor changes in membrane fluidity (Aricha et al., 2004; Zaritsky et al., 1985). Anisotropy values are inversely related to membrane fluidity (Shinitzky, 1984). Measurements were carried out as described in Cebrián et al. (2016) with some modifications. Briefly, samples of bacterial cultures were diluted, if necessary, to obtain an $\mathrm{OD}_{600}=0.80$, washed twice with PBS containing $0.25 \%$ formaldehyde (pH7.4) for fixation, and then incubated for $45 \mathrm{~min}$ at $37^{\circ} \mathrm{C}$ with $5 \times 10^{-6} \mathrm{M}$ DPH (added as a $10^{-4} \mathrm{M}$ solution in tetrahydrofuran) for probe insertion in the membrane. Steady-state fluorescence anisotropy was measured at the different established temperatures (between 54 and $62^{\circ} \mathrm{C}$ ) with a Cary-Eclipse spectrofluorometer provided with a thermostatized multicell holder and a manual polarizer accessory (Varian Inc., Mulgrave, Victoria, Australia) with excitation at $355 \mathrm{~nm}$ and emission at $425 \mathrm{~nm}, 2.5-$ and $2.5-\mathrm{nm}$ slits, respectively, and a 3-s integration time.

Anisotropy values (r) were calculated according to Shinitzky (1984):

$r=\frac{I_{V V}-G \cdot I_{V H}}{I_{V V}+2 \cdot G \cdot I_{V H}}$ with $G=\frac{I_{H V}}{I_{H H}}$

$\mathrm{V}$ and ${ }_{\mathrm{H}}$ stand for polarization direction (vertical and horizontal directions) I: corrected fluorescence intensity obtained by:

$$
\begin{aligned}
I_{\mathrm{HH}}= & I_{(\mathrm{L}) \mathrm{HH}}-I_{(\mathrm{BUFFER}+\mathrm{CELL}) \mathrm{HH}} \\
& -I_{(\mathrm{BUFFER}+\mathrm{PROBE}) \mathrm{HH}}+I_{(\mathrm{BUFFER}) \mathrm{HH}}
\end{aligned}
$$

$I_{(\mathrm{L})}$ : fluorescence intensity of probe-labelled cell suspension; $I_{\text {(BUFFER + CELL) }}$ : fluorescence intensity of non-labelled cell suspension; $I_{\text {(BUFFER + PROBE) }}$ : fluorescence intensity of the buffer incubated with the DPH probe; $I_{(\mathrm{BUFFER})}$ : fluorescence intensity of the sole buffer. This calculation was repeated for the other three signals $\left(I_{\mathrm{HV}}, I_{\mathrm{VV}}, I_{\mathrm{VH}}\right)$.

Fluorescence anisotropy determinations were performed at least three times on separate working days. Error bars in figures correspond to the mean, standard deviation.

\section{Results}

\subsection{Influence of growth temperature on $S$. aureus heat resistance: exponential growth phase cells}

Fig. $1 \mathrm{~A}$ shows the survival graphs to heat at $58^{\circ} \mathrm{C}$ of $S$. aureus exponential growth phase cells grown at $10,20,30,37$ and $42^{\circ} \mathrm{C}$. As can be observed, survival curves obtained for exponential growth phase cells displayed shoulders of varying length. Cells grown between 10 and $37^{\circ} \mathrm{C}$ showed a very similar thermotolerance, and no significant differences ( $p>0.05$ ) were found among either the $D_{58}$ values $(0.208-0.138 \mathrm{~min}$ ) or the $s l_{58}$ values $(0.146-0.090 \mathrm{~min})$. Conversely, cells grown at $42^{\circ} \mathrm{C}$ showed significantly higher $D_{58}(0.478 \mathrm{~min})$ and $s l_{58}(0.570 \mathrm{~min})$ values than cells grown between 10 and $37^{\circ} \mathrm{C}$. It is worth noting that the magnitude of the shoulder phenomena in the cell suspensions obtained at $42^{\circ} \mathrm{C}$ was particularly pronounced.

To determine the influence of treatment temperature on the calculated resistance parameters, we also obtained the survival curves to heat in the range between 54 and $62^{\circ} \mathrm{C}$ (data not shown). An exponen- tial relationship was always found between the $D$ values and the treatment temperature: thus it was possible to calculate, a $z_{D}$ value similar to the classical $z$ value. The $z_{D}$ value corresponds to the increase in temperature required for reducing the $D$ value by a factor of 10 . Our results demonstrate that the differences in the calculated $D$ values remained constant regardless of treatment temperature - at least in the range studied - and thus, no statistical differences $(p>0.05)$ were found between the $z_{D}$ values calculated for exponential phase cells grown at 10 , $20,30,37$ and $42^{\circ} \mathrm{C}\left(4.8^{\circ} \mathrm{C}\right.$ in average) (Table 1$)$.

From all these data it can be deduced that an increase in growth temperature did not result in greater heat resistance, except for cells grown at $42^{\circ} \mathrm{C}$. Our results contrast with the general assumption that increasing growth temperature results in an increase in heat resistance (Cebrián et al., 2008; Elliker and Frazier, 1938; Knabel et al., 1990; Mañas et al., 2003; Pagán et al., 1999). Since most of the results published in the literature have been obtained with stationary growth phase cells, we checked whether increasing growth temperature resulted in an increased heat resistance of $S$. aureus stationary growth phase cells.
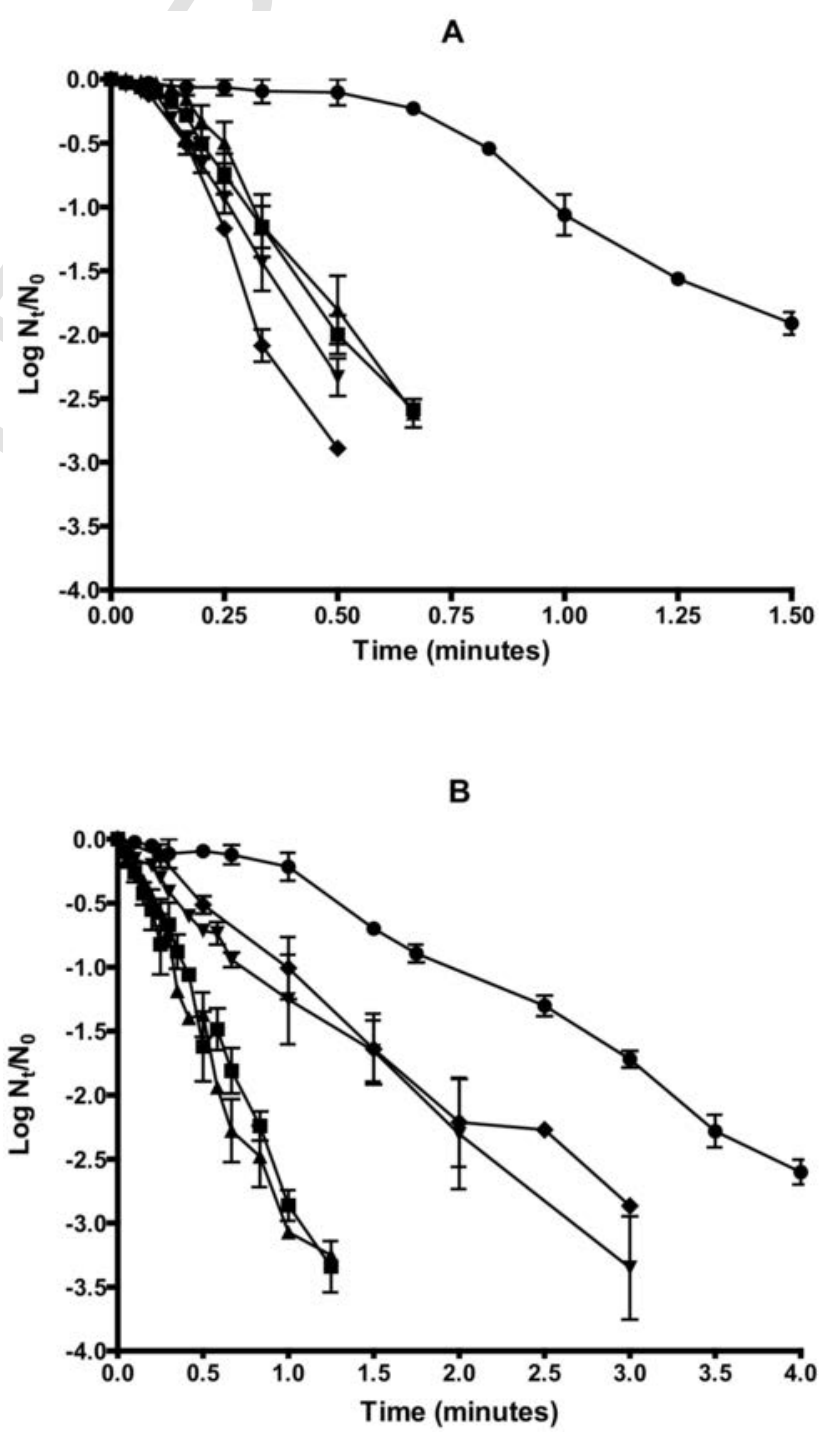

Fig. 1. Influence of growth temperature on the heat resistance $\left(58^{\circ} \mathrm{C}\right)$ of $S$. aureus CECT 4459 exponential (A) and stationary (B) growth phase cells grown at $10^{\circ} \mathrm{C}(\boldsymbol{\square}), 20^{\circ} \mathrm{C}(\boldsymbol{\Delta})$, $30^{\circ} \mathrm{C}(\boldsymbol{\nabla}), 37^{\circ} \mathrm{C}(\bullet)$ and $42^{\circ} \mathrm{C}(\bullet)$. Error bars correspond to the standard deviations. 


\subsection{Influence of growth temperature on S. aureus heat resistance: stationary growth phase cells}

The survival curves to heat at $58^{\circ} \mathrm{C}$ of $S$. aureus stationary phase cells grown at 10, 20, 30, 37 and $42^{\circ} \mathrm{C}$ are shown in Fig. 1B. S. aureus stationary phase cells grown at higher temperatures were more heat resistant than those grown at lower temperatures. As described for exponential growth phase cells, survival curves showed some shoulders; however, the shoulder phenomenon was of lower magnitude than in exponential phase cells, except for cells grown at $42{ }^{\circ} \mathrm{C}$ (Fig. 1B).

Furthermore, in this case, no significant differences $(p>0.05)$ in shoulder length $(s l)$ were found between cells grown between 10 and $37^{\circ} \mathrm{C}(0.091-0.143 \mathrm{~min})$; however, increasing growth temperature up to $42^{\circ} \mathrm{C}$ resulted in the appearance of a longer shoulder $(s l=0.859 \mathrm{~min})$ $(p<0.05)$. On the other hand, the increase in growth temperature resulted in an increase in the $D$ values from $0.324 \mathrm{~min}$ for cells grown at $10^{\circ} \mathrm{C}$ to $1.29 \mathrm{~min}$ for those grown at $42^{\circ} \mathrm{C}$. It should be noted that the relationship between growth temperature and heat resistance was not strictly linear, since no differences $(p>0.05)$ were found between $D$ values of cells grown at 10 and $20^{\circ} \mathrm{C}$, or between cells grown at 30 and $37^{\circ} \mathrm{C}$.

$Z_{D}$ values were very similar for stationary phase cells grown at the different temperatures: thus, the differences in $D$ values remained constant regardless of treatment temperature, within the range of treatment temperatures studied (Table 2).

\subsection{Cellular recovery in sodium chloride-added media}

Several authors have suggested that the increased resistance to heat observed in bacterial cells grown at higher temperatures might be due to an increased ability to repair sublethal damages caused by heat (Smith et al., 1991). To study this aspect, cells were also recovered in the presence of sodium chloride (selective medium) after heat treatment at $58^{\circ} \mathrm{C}$ in order to evaluate the occurrence of sublethally injured cells. s 2 .

No significant differences $(p>0.05)$ were found between either the $D$ or the $s l$ values calculated at $58^{\circ} \mathrm{C}$ for exponential growth phase cells grown between 10 and $37^{\circ} \mathrm{C}$, but both parameters were significantly $(p<0.05)$ higher for cells grown at $42^{\circ} \mathrm{C}$. Similarly, no significant differences $(p>0.05)$ were found between either the $D_{58}$ or the $s l_{58}$ values calculated for stationary growth phase cells grown between 10 and $37^{\circ} \mathrm{C}$, but both parameters were significantly $(p<0.05)$ higher for cells grown at $42^{\circ} \mathrm{C}$.

No significant differences ( $p>0.05$ ) were found among the $Z_{D}$ values calculated for stationary phase cells grown at the different temper-

Table 2

$z$ values $\left({ }^{\circ} \mathrm{C}\right)$ calculated for $S$. aureus CECT 4459 exponential and stationary growth phase cells when recovered in Non-Selective (TSAYE) and selective media (TSAYE $+\mathrm{NaCl}$ ). The table also includes the Standard Deviation (S.D.) of the $\mathrm{z}$ values.

\begin{tabular}{lllll}
\hline Growth temperature & \multicolumn{2}{l}{ Non-selective } & \multicolumn{2}{l}{ Selective } \\
\hline & $z_{D}$ & S.D. & $z_{D}$ & S.D. \\
\hline EXP GP & & & & \\
$10^{\circ} \mathrm{C}$ & 4.953 & 0.363 & 6.405 & 0.692 \\
$20^{\circ} \mathrm{C}$ & 4.914 & 0.178 & 8.111 & 0.218 \\
$30^{\circ} \mathrm{C}$ & 4.615 & 0.352 & 8.058 & 0.341 \\
$37^{\circ} \mathrm{C}$ & 4.944 & 0.427 & 7.579 & 0.813 \\
$42^{\circ} \mathrm{C}$ & 4.511 & 0.369 & 8.750 & 1.130 \\
$\mathrm{STAT} \mathrm{GP}$ & & & & \\
$10^{\circ} \mathrm{C}$ & 5.290 & 0.371 & 8.153 & 0.239 \\
$20^{\circ} \mathrm{C}$ & 5.049 & 0.370 & 8.629 & 0.625 \\
$30^{\circ} \mathrm{C}$ & 4.960 & 0.407 & 8.276 & 0.150 \\
$37^{\circ} \mathrm{C}$ & 5.388 & 0.234 & 8.589 & 0.427 \\
$42^{\circ} \mathrm{C}$ & 4.995 & 0.166 & 7.695 & 0.823 \\
\hline
\end{tabular}

atures when cells were recovered in selective medium. Thus, conclusions drawn for values calculated at $58^{\circ} \mathrm{C}$ could apply to the entire range of treatment temperatures studied (Table 2).

\subsection{Exponential vs stationary growth phase cells and selective vs non-} selective recovery medium

Fig. 2 includes the $D$ and shoulder length $(s l)$ values at $58^{\circ} \mathrm{C}$ calculated for cells grown at the five temperatures and recovered in the two media used - i.e. selective and non-selective - for better comparison.

The comparison of results obtained for exponential and stationary growth phase cells leads to a series of observations. Firstly, whereas for exponential growth phase cells an increase in growth temperature up to $37^{\circ} \mathrm{C}$ did not result in a significant change in heat resistance, it did for stationary growth phase cells. Secondly, entry into stationary growth phase resulted in an increase in $D$ values regardless of growth temperature, but this increase was more pronounced for cells grown at higher temperatures. For instance, $D_{58}$ value increased almost 6 -fold for cells grown at $37^{\circ} \mathrm{C}$, and only 1.4 -fold for cells grown at $20^{\circ} \mathrm{C}$ (Fig.

A

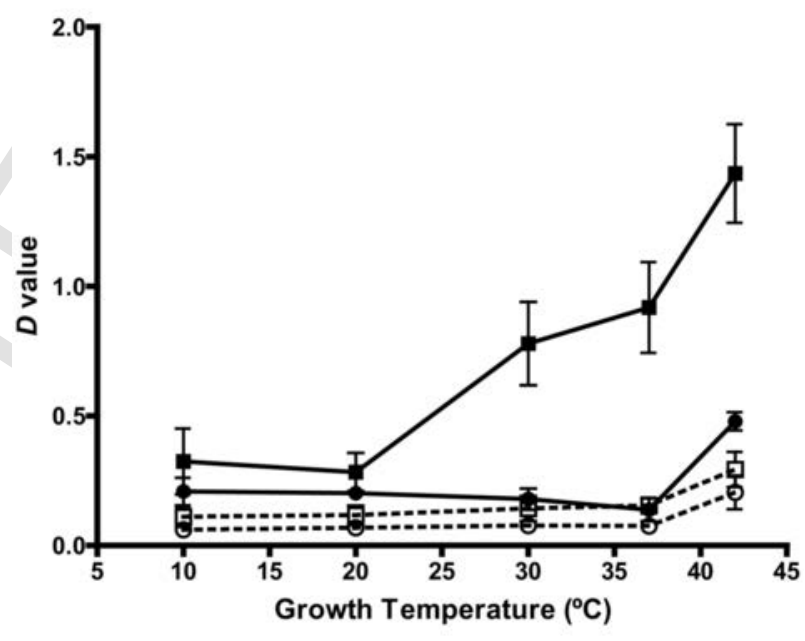

B

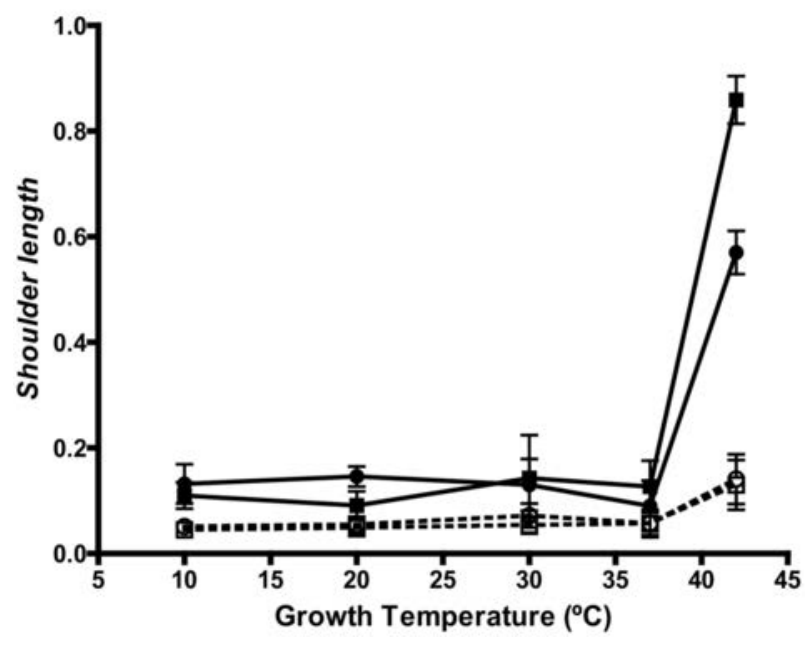

Fig. 2. Influence of growth temperature on the $D_{58}$ values (minutes) (A) and shoulder length $(s l)_{58}$ values (minutes) (B) calculated for exponential $(\bullet, O)$ and stationary $(\square, \square)$ growth phase $S$. aureus CECT 4459 cells recovered in non-selective (close symbols, continuous line) and selective medium (open symbols, discontinuous line). Error bars correspond to the standard deviations. 
2A). In fact, the increase was only statistically significant for cells grown at temperatures of 30,37 and $42^{\circ} \mathrm{C}$. Moreover, entry into stationary growth phase did not result in any significant change in shoulder length, except for cells grown at $42^{\circ} \mathrm{C}$ (Fig. 2B).

On the other hand, if data obtained in non-selective recovery media are compared with those obtained in selective media, it can be observed that recovery in selective media always resulted in a reduction of the $D_{58}$ and $s l_{58}$ parameters, regardless of growth phase and temperature (Table 1 and Fig. 2A and B); however, the magnitude of the decrease in these parameters varied. For exponential growth phase cells, the magnitude of decrease in the $D_{58}$ values was similar for all suspensions (1.8 to 3 -fold). Similar results were found for $s l$ values calculated for cells grown between 10 and $37^{\circ} \mathrm{C}$, except for cells grown at $42^{\circ} \mathrm{C}$, for which a 4-fold decrease in the $s l_{58}$ was observed (Fig. 2B). Stationary growth phase cells grown at 10 and $20^{\circ} \mathrm{C}$ displayed a similar behavior to that of exponential growth phase cells grown between 10 and $37^{\circ} \mathrm{C}$; but when grown at $30^{\circ} \mathrm{C}$ or above, the difference between the $D_{58}$ values calculated in non-selective and selective medium increased up to 6 -fold. In addition, stationary growth phase cells cultivated at $42^{\circ} \mathrm{C}$ also displayed a significant increase in the ratio between the shoulder length values obtained in the different media (6.6-fold for cells grown at $42{ }^{\circ} \mathrm{C} v s$-fold for cells grown at other temperatures).

It is noteworthy that, when resistance parameters were determined in selective media, entry into stationary growth phase resulted in increases of low magnitude, approximately 2 -fold, which were only statistically significant for cells grown at 30 and $37^{\circ} \mathrm{C}(p<0.05)$.

Finally, $z$ values calculated were significantly higher $(p<0.05)$ when cells were recovered in selective medium than in non-selective medium, regardless of growth phase and temperature. Therefore, the proportion of sublethally damaged cells capable of recovery would be lower, the higher the treatment temperature.

\subsection{DPH fluorescence anisotropy values of $S$. aureus cells grown at different temperatures: relation to heat resistance}

The heat resistance of bacterial cells grown at higher temperatures has also been attributed to the lower fluidity of their membranes. In order to check this hypothesis, we also studied the fluidity, at lethal temperatures, of the membranes of cells grown at different temperatures and in different growth phases by using the fluorescent dye DPH. Fig. 3 shows the anisotropy values $(r)$ obtained at $58^{\circ} \mathrm{C}$ for $S$. aureus exponential and stationary growth phase cells grown at different temperatures. Anisotropy values are inversely related to membrane fluidity (Shinitzky, 1984).

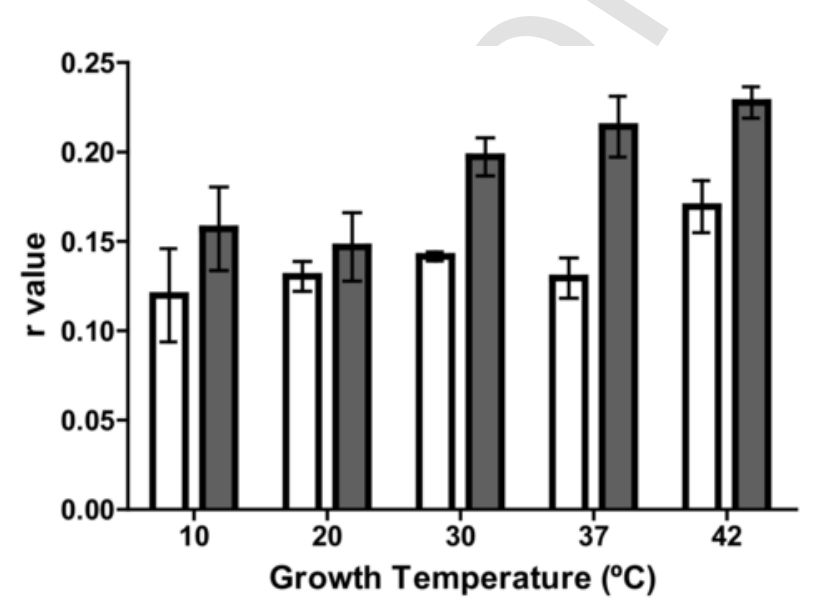

Fig. 3. Influence of growth temperature on the fluorescence anisotropy values ( $r$ ) calculated at $58^{\circ} \mathrm{C}$ for $S$. aureus CECT 4459 exponential (white bars) and stationary (grey bars) growth phase cells. Error bars correspond to the standard deviations.
As can be observed, exponential growth phase cells grown in the range between 10 and $37^{\circ} \mathrm{C}$ showed the same fluorescence anisotropy values $(p>0.05)$, whereas cells grown at $42^{\circ} \mathrm{C}$ showed more rigid membranes $(p<0.05)$. Regarding stationary growth phase cells, cells grown at lower temperatures displayed lower anisotropy values than those grown at higher temperatures $(p<0.05)$. It should also be noted that, in most cases, entry into stationary growth phase resulted in an increase in fluorescence anisotropy of bacterial membranes, i.e. membranes were more rigid in stationary phase cells. This increase was more pronounced for cells grown at the higher temperatures, similarly to that observed for heat resistance (Fig. 2). Measurements were also obtained at other temperatures between 54 and $62^{\circ} \mathrm{C}$, and the trend was similar for exponential and stationary phase cells (data not shown).

Fig. 4 illustrates the relationship between fluorescence anisotropy and heat resistance at $58^{\circ} \mathrm{C}$ ( $D$ values). It includes data corresponding to exponential and stationary phase cells. A highly significant relationship (Pearson coefficient $=0.969 * * *$ ) was observed between membrane fluidity as measured by fluorescence anisotropy and $D$ values calculated when cells were recovered in non-selective media. On the other hand, no significant correlation was found between fluorescence anisotropy and $s l$ values (data not shown).

\subsection{Influence of the addition of a membrane fluidizer on heat resistance and occurrence of sublethal injury}

In order to further investigate if there was a relationship between heat survival and membrane fluidity, we adopted a complementary experimental approach: the exposition of $S$. aureus cells to the action of benzyl alcohol (BA). BA has been used as a membrane fluidizer, and its use is preferred over other alcohols (such as ethanol), because it causes no protein denaturation at the concentrations and times required to fluidize bacterial membranes, at least at room temperatures (Shigapova et al., 2005). Cells grown at $37^{\circ} \mathrm{C}$ were treated in media containing BA at different concentrations $(0,5,10,20 \mathrm{mM})$. Heat resistance at $58^{\circ} \mathrm{C}$ was determined using non-selective and selective recovery media, and the membrane DPH anisotropy was measured at the same temperature. Results are displayed in Fig. 5. As shown in the graph, exposure of $S$. aureus cells to increasing concentrations of BA produced a gradual drop in $r$ values: in other words, it produced a detectable fluidization of the membrane. In parallel, the heat resistance of $S$. aureus cells decreased progressively in the two recovery media used. Fig. 6 shows that the sensitizing effect of benzyl alcohol was maintained across the different

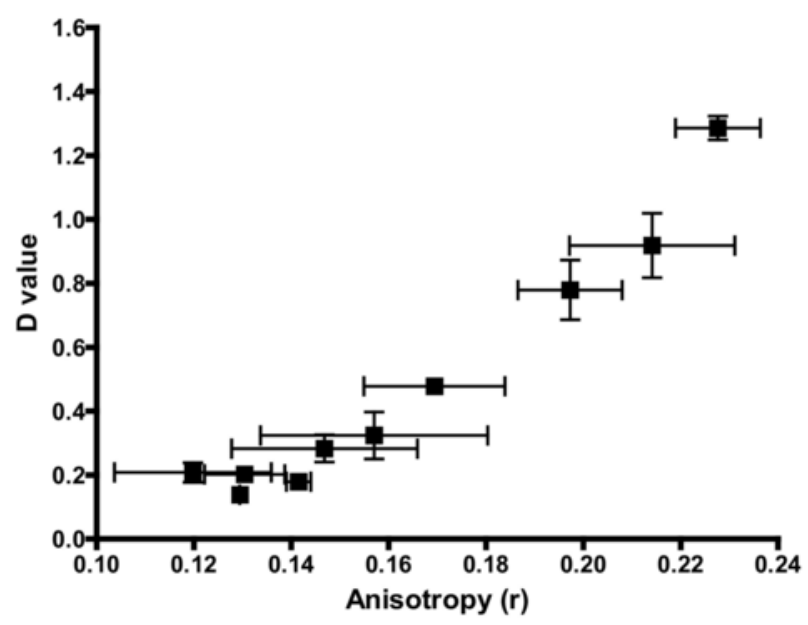

Fig. 4. Relationship between the fluorescence anisotropy $\left(r_{58}\right)$ and $D_{58}$ values (min utes) calculated for $S$. aureus CECT 4459 recovered in non-selective media. Error bars correspond to the standard deviations. 


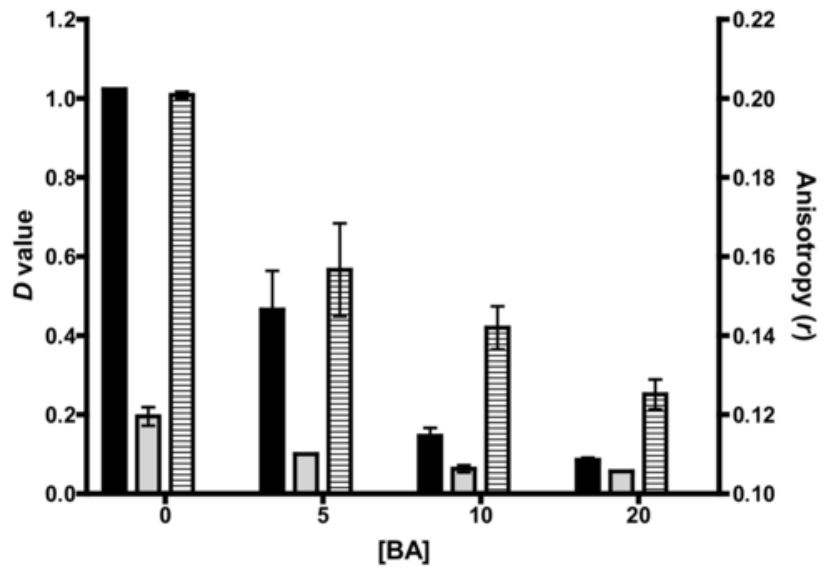

Fig. 5. Influence of the concentration of $\mathrm{BA}(\mathrm{mM})$ on the $D$ values $\left(58^{\circ} \mathrm{C}\right.$; minutes) determined in non-selective (black bars) and selective medium (grey bars) and on the fluorescence anisotropy values ( $r$ ) (stripped bars) of $S$. aureus stationary growth phase cells grown at $37^{\circ} \mathrm{C}$. Error bars correspond to the standard deviations.

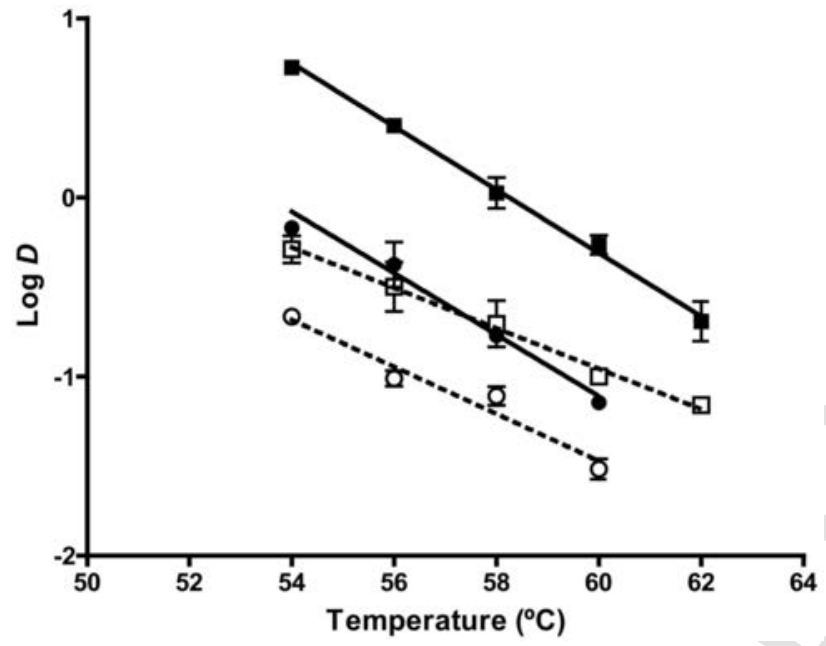

Fig. 6. Influence of treatment temperature on the $D$ values (minutes) determined in nonselective medium (full symbols, continuous lines) and selective medium (empty symbols, discontinuous lines) of stationary growth phase cells $S$. aureus CECT 4459 cells grown at $37^{\circ} \mathrm{C}$ treated without (squares) or with $10 \mathrm{mM}$ Benzyl-alcohol (circles). Error bars correspond to the standard deviations.

treatment temperatures, since the $z$ values obtained in non-selective recovery medium were equivalent for control cells $\left(5.6 \pm 0.39^{\circ} \mathrm{C}\right)$ and for cells exposed to $10 \mathrm{mM}$ BA $\left(5.8 \pm 0.46^{\circ} \mathrm{C}\right)$. Similarly, $z$ values obtained in selective media did not significantly $(p>0.05)$ differ $(8.7 \pm 0.45 v s$ $\left.7.6 \pm 0.95^{\circ} \mathrm{C}\right)$

\section{Discussion}

In this study, the influence of growth temperature on Staphylococcus aureus survival to heat was investigated. The mechanisms behind the changes in resistance were also explored with special emphasis on the influence of the physiological state of cells, the occurrence of sublethal damages, and the relationship with membrane fluidity.

Survival curves of $S$. aureus suspensions exposed to heat proved to be non-linear: therefore, a special case of the Baranyi and Roberts model and the DMfit software was used to fit experimental data. The advantages of this model for this purpose have been discussed elsewhere (Xiong et al., 1999). Alternatively, the model of Geeraerd (based on the same mirror image of the Baranyi-Roberts growth model) might have been used (Geeraerd et al., 2005).
The appearance of shoulders in survival graphs to heat of vegetative microbial cells has been attributed to different phenomena, including cell aggregation and phenomena related to the ability of cells to withstand or repair sublethal damages (Condón et al., 1996; Hansen and Riemann, 1963; Mackey, 2000; Pagán et al., 1997). Concerning the shoulders observed in this investigation for survival curves to heat of $S$. aureus cells, our results suggest that their nature could be different depending on the conditions used to obtain the cell suspension. It is well known that $S$. aureus is a bacterial species that frequently forms aggregates (Baird-Parker, 2000). In our study, we found that exponential phase suspensions grown at $10,20,30$ and $37^{\circ} \mathrm{C}$ contained aggregates of 4.3 cells in average. This could account for an apparent decrease in the initial number of microorganisms in survival curves of 0.64 Log cycles, and, therefore, could explain the occurrence of the shoulders observed in the survival curves of these cells (Fig. 1A). The same calculation can be made for the other suspensions and recovery conditions: in most cases, the presence of cell aggregates can be linked to the presence of shoulders, including survival curves obtained in selective medium. However, for bacterial suspensions grown at $42{ }^{\circ} \mathrm{C}$, shoulders observed in non-selective media were longer than expected according to the size of the aggregates. Thus, additional phenomena may play a role, most probably phenomena related with sublethal damage repair. In other words, cells grown at $42^{\circ} \mathrm{C}$ would display an increased ability to withstand and repair sublethal damage.

Regarding the influence of growth temperature on bacterial heat resistance, it is generally acknowledged that cells grown at higher temperatures display a greater thermal resistance (Elliker and Frazier, 1938; Jay, 1992; Kaur et al., 1998; Knabel et al., 1990; Pagán et al., 1999). Results obtained in this investigation only partially concur with those observations, since they depended on the growth temperature range and the physiological state of the cells. Whereas increasing growth temperature above $20^{\circ} \mathrm{C}$ resulted in an increase in heat resistance for stationary growth phase cells, for those in exponential growth phase a significant increase in resistance to heat was observed only when incubation temperature was raised to $42^{\circ} \mathrm{C}$. One possible explanation for the different behaviors observed when comparing results obtained in this research and previous studies is that they were mostly carried out with stationary growth phase cells, whereas in this investigation both exponential and stationary growth phase cells were used. Nevertheless, it is also feasible that each bacterial species might display a specific response to modifications in growth temperature.

Recovery in media with added $\mathrm{NaCl}$ allowed us to evaluate the occurrence of cells with sublethal damages since it is generally assumed that cells with damaged membranes are unable to grow in the presence of $\mathrm{NaCl}$. Therefore, sublethal injury detected by this differential plating technique is generally ascribed to the presence of cells with damages in the membrane (Mackey, 2000). Results obtained in this work indicate that, for stationary growth phase suspensions grown between 10 and $37^{\circ} \mathrm{C}$, the number of $S$. aureus cells with lethal damages after a heat treatment would be very similar regardless of growth temperature, because little difference in the $D$ values calculated in selective media was observed among these suspensions. Consequently, the increase in growth temperature from 10 to $37^{\circ} \mathrm{C}$ would result in the gradual appearance of a higher proportion of sublethally damaged cells capable of repairing their lesions and resuming normal growth in non-selective media. Conversely, when cells were grown at $42^{\circ} \mathrm{C}$, the increase in heat resistance observed when cells were recovered in non-selective medium, was also accompanied by an significant increase when recovery was carried out in selective medium i.e. it resulted not only in an increased number of survivors, but also in a decrease in the number of cells with permanently damaged membranes. In other words, the membranes of cells grown at $42^{\circ} \mathrm{C}$ are probably more thermostable. One also should bear in mind that the survival graphs of cells grown at $42{ }^{\circ} \mathrm{C}$ invariably displayed longer shoulders than the rest. 
Our results also showed that entry into stationary growth phase would lead to an increase in heat resistance for $S$. aureus cells, mainly due to a decrease of the inactivation rate in the survival curve's linear region $\left(D_{58} \times 1.4-6.7\right)$. This increase in resistance was of lower magnitude in cells grown at the lowest temperatures. Moreover, when cells were recovered in selective media, entry into stationary growth phase resulted in a lower increase in heat tolerance $\left(D_{58} \times 1.6-2.0\right)$, which was not even statistically significant for most cell suspensions.

Taken together, all of these results suggest that, in S. aureus, the growth-temperature-dependent increase in heat resistance would rely on mechanisms triggered upon entry into the stationary phase of growth and would be mainly related with an increase in the ability of cells to overcome damages caused by heat. Thus, it can be hypothesized that this phenomenon might be related to stationary phase resistance factors, such as, for instance, a higher expression of the general stress sigma factor $\operatorname{sig} B$, as described in Cebrián et al. (2009). Further work is in progress to clarify these aspects. In addition, in cells grown at $42{ }^{\circ} \mathrm{C}$, growth-phase-independent resistance mechanisms causing an increase in the membrane's thermal stability would also contribute to their higher thermal tolerance. It should be pointed out that it cannot be discarded that heat may provoke sublethal damages of different intensity, depending on the structure and composition of the membranes in each particular cell suspension, and that the damages cannot be distinguished with the selective plating technique used here. This would imply that cells grown at the lowest temperatures would suffer more severe sublethal injuries, and would be less prone to be repaired by the cellular machinery.

The role that membrane stability might play in bacterial heat resistance has attracted much attention for various reasons. The membrane is regarded as one of the main cellular target structures of heat inactivation (Mackey, 2000; Tomlins and Ordal, 1976) and it is also considered to be one of the structures that suffer the most important modifications as a consequence of an increase in growth temperature (Beuchat, 1978; Denich et al., 2003). Thus, the ultimate aim of our study was to determine whether those cells displaying a higher heat resistance also had a less fluid membrane. For this purpose we used fluorescence anisotropy as a method to assess the membrane fluidity of $S$. aureus cells. The major advantages and drawbacks of this technique have already been discussed in depth (Denich et al., 2003). In this particular research, fluorescence anisotropy permitted us to obtain data at the same temperatures at which cells were treated, which allowed us to establish meaningful relationships between membrane fluidity and heat resistance. Nevertheless, one should note that fluorescence anisotropy values should be interpreted only as an index of average membrane fluidity, since bacterial membranes have regions possessing different degrees of organization and fluidity (Bramkamp and Lopez, 2015).

According to our results, the membrane fluidity of exponential growth phase cells grown between 10 and $37^{\circ} \mathrm{C}$, measured at lethal temperatures, was similar, and only those cells grown at $42^{\circ} \mathrm{C}$ showed a significantly higher $r$ value. This pattern of fluidity was coincident with the pattern of heat resistance. For stationary phase cells a similar trend was observed, and the most heat resistant cells showed higher $r$ values, indicating a more rigid membrane. Thus, $S$. aureus cells with more rigid membranes showed greater heat resistance. Besides, according to the discussion above, a more rigid membrane would also favor cellular repair processes after treatment. Alternatively, it is also possible that a more rigid membrane would become less severely damaged after heat exposure, and would thus be more easily repairable under suitable conditions. However, it can be argued that changes in membrane fluidity induced by growth temperature may be accompanied by other cellular physiological changes that could also play a relevant role in heat resistance. In order to clarify the actual role of membrane fluidity, cells grown at a fixed temperature $\left(37^{\circ} \mathrm{C}\right)$ were exposed to benzyl alcohol. The results obtained with benzyl alcohol demonstrate that membrane fluidity is per se an important factor in survival to heat, since a given cell population exposed to the fluidizer showed a sensitization to heat in a concentration-dependent manner. In addition, this sensitizing effect was of notable magnitude. For instance, $D_{58}$ value was reduced by a factor of 10 in the presence of the fluidizer at a concentration of $20 \mathrm{mM}$. We specifically checked that the degree of protein precipitation in $S$. aureus cells heated at $58^{\circ} \mathrm{C}$ in the presence and absence of $20 \mathrm{mM}$ benzyl alcohol was equivalent (data not shown): thus, relevant detrimental effects of this compound on cell proteins can be excluded, as already indicated by Shigapova et al. (2005). We can therefore conclude that $S$. aureus cells with a more fluid membrane are more heat-sensitive than equivalent cells with a more rigid membrane, independently of other possible cellular changes induced in response to growth temperature.

The effect of benzyl alcohol on heat resistance of $S$. aureus was maintained along the entire range of treatment temperatures studied. This sensitization effect was equally observed when cells were recovered in a selective medium, and it was also maintained across the different temperatures. This would indicate, on the one hand, that a more fluid membrane would be more thermosensitive and, on the other hand, that in spite of the cell's global sensitization to heat, recovery mechanisms remained effective in a similar degree in cells with fluidized membranes.

Finally, it should be noted that an increase in treatment temperature was not accompanied by a significant decrease $(p>0.05)$ in membrane fluidity within the range studied $\left(54-62^{\circ} \mathrm{C}\right.$; data not shown). This strongly suggests that although membrane fluidization favors the thermal inactivation of $S$. aureus, it would not be the sole or ultimate cause of cell death.

\section{Concluding remarks}

Results reported herein demonstrate that increasing growth temperature leads to a greater rigidity of membranes at treatment temperatures; moreover, a significant correlation between that parameter and cellular heat resistance was found. We have proven that cells exposed to a fluidizer compound (benzyl alcohol), and thus with a more fluid membrane, are sensitized against the action of heat. According to this data, the physical state of the membrane is an important factor determining the survival capacity of $S$. aureus cells to a heat treatment. Additional physiological factors influencing the thermotolerance of cells grown at different temperatures cannot be excluded. From an applied point of view, it should be noted that results here reported might be very useful for thermal treatment design and optimization and/or for microbial risk assessment studies.

Supplementary data to this article can be found online at https:// doi.org/10.1016/j.ijfoodmicro.2018.09.002.

\section{Uncited reference}

Sinensky, 1974

\section{Acknowledgements}

The authors would like to thank the Ministerio de Economía y Competitividad, EU-FEDER (project AGL-2015-69565-P) and the Department of Science, Technology and University of the Aragon Government for the support.

\section{References}

Abee, T., Wouters, J.A., 1999. Microbial stress response in minimal processing. Int. J. Food Microbiol. 50, 65-91.

Aricha, B., Fishov, I., Cohen, Z., Sikron, N., Pesakhov, S., Khozin-Goldberg, I., Dagan, R., Nurith, P., 2004. Differences in membrane fluidity and fatty acid composition be- 
tween phenotypic variants of Streptococcus pneumoniae. J. Bacteriol. 186, 4638-4644.

Baird-Parker, T.C., 2000. Staphylococcus aureus. In: Lund, B.M., Baird-Parker, T.C., Gould, G.W. (Eds.), The Microbiological Safety and Quality of Foods. Aspen Publishers, Inc., Gaithersburg, Maryland, pp. 1317-1335.

Baranyi, J., Roberts, T.A., 1994. A dynamic approach to predicting bacterial-growth in food. Int. J. Food Microbiol. 23, 277-294.

Baranyi, J., Jones, A., Walker, C., Kaloti, A., Robinson, T.P., Mackey, B.M., 1996. A combined model for growth and subsequent thermal inactivation of Brochothrix thermosphacta. Appl. Environ. Microbiol. 62, 1029-1035.

Beuchat, L.R., 1978. Injury and repair of gram negative bacteria, with special consideration of the involvement of the cytoplasmic membrane. Adv. Appl. Microbiol. 23, 219-243.

Beuchat, L.R., Worthington, R.E., 1976. Relationships between heat resistance and phospholipid fatty acid composition of Vibrio parahaemolyticus. Appl. Environ. Microbiol. 31, 389-394.

Bramkamp, M., Lopez, D., 2015. Exploring the existence of lipid rafts in bacteria. Microbiol. Mol. Biol. Rev. 79, 81-100.

Cebrián, G., Sagarzazu, N., Pagán, R., Condón, S., Mañas, P., 2008. Resistance of Escherichia coli grown at different temperatures to various environmental stresses. J. Appl. Microbiol. 105, 271-278.

Cebrián, G., Sagarzazu, N., Aertsen, A., Pagan, R., Condón, S., Manas, P., 2009. Role of the alternative sigma factor $\sigma^{\mathrm{B}}$ on Staphylococcus aureus resistance to stresses of relevance to food preservation. J. Appl. Microbiol. 107, 187-196.

Cebrián, G., Arroyo, C., Mañas, P., Condón, S., 2014. Bacterial maximum non-inhibitory and minimum inhibitory concentrations of different water activity depressing solutes. Int. J. Food Microbiol. 188, 67-74.

Cebrián, G., Condon, S., Mañas, P., 2016. Influence of growth and treatment temperature on Staphylococcus aureus resistance to pulsed electric fields: relationship with membrane fluidity. Innovative Food Sci. Emerg. Technol. 37, 161-169.

Cebrián, G., Condón, S., Mañas, P., 2017. Physiology of the inactivation of vegetative bacteria by thermal treatments: mode of action, influence of environmental factors and inactivation kinetics. Foods 6, 107.

Condón, S., Arrizubieta, M.J., Sala, F.J., 1993. Microbial heat resistance determinations by the multipoint system with the thermoresistometer TR-SC. J. Microbiol. Methods 18, 357-366.

Condón, S., Palop, A., Raso, J., Sala, F.J., 1996. Influence of the incubation temperature after heat treatment upon the estimated heat resistance values of spores of Bacillus subtilis. Lett. Appl. Microbiol. 22, 149-152.

Coote, P.J., Jones, M.V., Seymour, I.J., Rowe, D.L., Ferdinando, D.P., McArthur, A.J., Cole, M.B., 1994. Activity of the plasma membrane $\mathrm{H}^{+}$-ATPase is a key physiological determinant of thermotolerance in Saccharomyces cerevisiae. Microbiology 140, 1881-1890.

Coucheney, F., Gal, L., Beney, L., Lherminier, J., Gervais, P., Guzzo, J., 2005. A small HSP, Lo18, interacts with the cell membrane and modulates lipid physical state under heat shock conditions in a lactic acid bacterium. Biochim. Biophys. Acta 1720, 92-98.

Dawson, R.M.C., Elliot, D.C., Elliot, W.H., Jones, K.M., 1974. Data for Biochemical Research. Oxford at Clarendon Press, Oxford.

Denich, T.J., Beaudette, L.A., Lee, H., Trevors, J.T., 2003. Effect of selected environmental and physico-chemical factors on bacterial cytoplasmic membranes. J. Microbiol. Methods 52, 149-182.

Elliker, P.R., Frazier, W.C., 1938. Influence of time and temperature of incubation on heat resistance of Escherichia coli. J. Bacteriol. 36, 83-98.

Geeraerd, A., Valdramidis, V., Van Impe, J., 2005. GInaFiT, a freeware tool to assess non-log-linear microbial survivor curves. Int. J. Food Microbiol. 102, 95-105.

Hansen, N.H., Riemann, H., 1963. Factors affecting the heat resistance of nonsporing organisms. J. Appl. Bacteriol. 26, 314-333.

Herendeen, S.L., Vanbogelen, R.A., Neidhardt, F.C., 1979. Levels of major proteins of Escherichia coli during growth at different temperatures. J. Bacteriol. 139, 185-194.

Hurst, A., Hughes, A., Beare-Rogers, J.L., Collins-Thompson, D.L., 1973. Pysiological studies on the recovery of salt tolerance by Staphylococcus aureus after sublethal heating. J. Bacteriol. 116, 901-907.

Jay, J.M., 1992. High temperature food preservation, and characteristics of thermophilic microorganisms. In: Jay, J.M. (Ed.), Modern Food Microbiology, fourth ed. Chapman \& Hall, New York, pp. 335-355.
Kaur, J., Ledward, D.A., Park, R.W., Robson, R.L., 1998. Factors affecting the heat resistance of Escherichia coli O157:H7. Lett. Appl. Microbiol. 26, 325-330.

Knabel, S.J., Walker, H.W., Hartman, P.A., Mendonca, A.F., 1990. Effects of growth temperature, \& strictly anaerobic recovery on the survival of Listeria monocytogenes during pasteurization. Appl. Environ. Microbiol. 56, 370-376.

Kramer, B., Thielmann, J., 2016. Monitoring the live to dead transition of bacteria during thermal stress by a multi-method approach. J. Microbiol. Methods 123, 24-30.

Lim, B., Gross, C.A., 2010. Cellular response to heat shock and cold shock. In: Storz, G., Hengge, R. (Eds.), Bacterial Stress Responses, second ed. ASM Press, Washington D.C., pp. 93-114.

Mackey, B.M., 2000. Injured bacteria. In: Lund, B.M., Baird-Parker, T.C., Gould, G.W. (Eds.), The Microbiological Safety and Quality of Foods. Aspen Publishers, Inc., Gaithersburg, Maryland, pp. 315-341.

Mackey, B.M., Miles, C.A., Parsons, S.E., Seymour, D.A., 1991. Thermal denaturation of whole cells, \& cell components of Escherichia coli examined by differential scanning calorimetry. J. Gen. Microbiol. 137, 2361-2374.

Mañas, P., Pagán, R., Raso, J., Condón, S., 2003. Predicting thermal inactivation in media of different $\mathrm{pH}$ of Salmonella grown at different temperatures. Int. J. Food Microbiol. 2003 (87), 45-53.

Marcén, M., Ruiz, V., Serrano, M.J., Condón, S., Mañas, P., 2017. Oxidative stress in E. coli cells upon exposure to heat treatments. Int. J. Food Microbiol. 241, 198-205.

Pagán, R., Condón, S., Sala, F.J., 1997. Effects of several factors on the heat-shock-induced thermotolerance of Listeria monocytogenes. Appl. Environ. Microbiol. 63, 3225-3232.

Pagán, R., Mañas, P., Raso, J., Sala-Trepat, F.J., 1999. Heat resistance of Yersinia enterocolitica grown at different temperatures and heated in different media. Int. J. Food Microbiol. 47, 59-66.

Raso, J., Barbosa-Cánovas, G.V., 2003. Nonthermal preservation of foods using combined processing techniques. Crit. Rev. Food Sci. Nutr. 43, 265-285.

Russell, N.J., 1984. Mechanisms of thermal adaptation in bacteria: blueprints for survival. Trends Biochem. Sci. 9, 108-112.

Schumann, W., 2007. Thermosensors in eubacteria: role and evolution. J. Biosci. 32, 549-557.

Shigapova, N., Török, Z., Balogh, G., Goloubinoff, P., Vígh, L., Horváth, I., 2005. Membrane fluidization triggers membrane remodeling which affects the thermotolerance in Escherichia coli. Biochem. Biophys. Res. Commun. 328, 1216-1223.

Shinitzky, M., 1984. Membrane fluidity and cellular functions. In: Shinitzky, M. (Ed.), Physiology of Membrane Fluidity. I, CRC Press, Boca Raton, pp. 1-51.

Smith, J.L., Marmer, B.S., Benedict, R.C., 1991. Influence of growth temperature on injury and death of Listeria monocytogenes Scott A during a mild heat treatment. J. Food Prot. 54, 166-169.

Stintzi, A., 2003. Gene expression profile of Campylobacter jejuni in response to growth temperature variation. J. Bacteriol. 185, 2009-2016.

Teixeira, P., Castro, H., Mohácsi-Farkas, C., Kirby, R., 1997. Identification of sites of injury in Lactobacillus bulgaricus during heat stress. J. Appl. Microbiol. 83, 219-226.

Tomlins, R.I., Ordal, Z.J., 1976. Thermal injury and inactivation in vegetative bacteria. In: Skinner, F.A., Hugo, W.B. (Eds.), Inhibition and Inactivation of Vegetative Microbes. Academic Press, London, pp. 153-190.

Török, Z., Horváth, I., Goloubinoff, P., Kovács, E., Glatz, A., Balogh, G., Vigh, L., 1997. Evidence for a lipochaperonin: association of active protein-folding GroESL oligomers with lipids can stabilize membranes under heat shock conditions. Proc. Natl. Acad. Sci. U. S. A. 94, 2192-2197.

Tsvetkova, N.M., Horváth, I., Török, Z., Wolkers, W.F., Balogi, Z., Shigapova, N., Crowe, L.M., Tablin, F., Vierling, E., Crowe, J.H., Vigh, L., 2002. Small heat-shock proteins regulate membrane lipid polymorphism. Proc. Natl. Acad. Sci. U. S. A. 99, 13504-13509.

Xiong, R., Xie, G., Edmondson, A.E., Linton, R.H., Sheard, M.A., 1999. Comparison of the Baranyi model with the modified Gompertz equation for modelling thermal inactivation of Listeria monocytogenes Scott A. Food Microbiol. 16, 269-279.

Zaritsky, A., Parola, A.H., Ibdah, M., Masalha, H., 1985. Homeoviscous adaptation, growth rate, and morphogenesis in bacteria. Biophys. J. 48, 337-339. 
$-\min \min$ 